\title{
E-BRIEF
}

November 3, 2016

MONETARY POLICY

\section{Putting Money to Work: Monetary Policy in a Low Interest Rate Environment}

by

Steve Ambler

- Depending on the performance of the Canadian economy and the outlook for inflation, the Bank of Canada may, in the near future, decide to lower its overnight rate target to 25 basis points.

- It may then be faced with the necessity of providing monetary stimulus in an environment with a very low or even a negative overnight rate.

- I suggest here that it should use quantitative easing (QE) in order to affect inflation expectations and spending via an increase in the broad money supply, on a longer term rather than a temporary basis, to encourage spending on goods and services by individuals and firms. QE can stimulate the economy without having to drive down interest rates.

The drop in the world price of oil in 2014 was a significant negative shock to Canadian GDP and real income, prompting the Bank of Canada to lower its overnight rate target twice in the first seven months of 2015. Depending on the evolution of the outlook for the economy, the Bank may decide to lower the overnight rate target further to 25 basis points. At that point, its scope for further easing of monetary policy by lowering interest rates becomes quite limited as it hits an effective lower bound.

The author thanks Jeremy Kronick, David Laidler, David Dodge, Pierre Duguay, Nicholas Rowe and James MacGee for useful discussions and anonymous referees for useful comments, while remaining responsible for any remaining errors. 
Governor Poloz (Poloz 2015) signalled the possibility of using negative interest rates as a policy tool in a speech in December 2015 but how low they can go is limited. ${ }^{1}$ Further down the road, therefore, the Bank may then be faced with the necessity of providing monetary stimulus without lowering rates.

If these events come to pass, the Bank would find itself in a situation similar to 2009 during the Great Recession. Its target for the overnight rate remained at 25 basis points between April 2009 and the beginning of June 2010. The policy rates of other central banks have been close to or at their effective lower bound for different lengths of time since the onset of the Great Recession. For example, the Federal Reserve Bank lowered its target for the Federal Funds Rate to 25 basis points in December 2008, and only raised it to 50 basis points in December 2015.

I suggest in this E-Brief that the Bank should consider using quantitative easing $(\mathrm{QE})$ to affect spending by acting to expand the size of the money stock. ${ }^{2} \mathrm{QE}$ involves open market purchases of government securities from banks or from the private sector. Buying securities from banks increases the cash balances they hold at the Bank, thereby expanding the Bank's balance sheet. Banks can use these balances to expand lending, which expands deposits held by their customers and thereby expands broader measures of the money supply. Purchases of securities from the private sector expand bank deposits and broad money directly. These in turn encourage increased spending on goods and services without necessarily having to lower interest rates.

\section{Conventional Monetary Policy}

During the inflation-targeting era, "conventional" monetary policy has come to mean influencing a short-term nominal interest rate in order to influence other market interest rates at short and longer horizons and thereby influence spending. By altering spending, the amount of slack in the economy (measured by the output gap) is affected, which puts upward or downward pressure on the rate of inflation. This is the Bank of Canada's own view of how its monetary policy works as outlined in Bank of Canada (2012). The document also outlines three other channels for the transmission of monetary policy - the prices of various assets such as bonds, stocks and houses, the exchange rate, and expectations of future interest rates, inflation and growth - but these channels interact directly or indirectly with the first.

1 The speech outlined the tools available to the Bank in a low interest rate environment. Aside from negative interest rates, he noted that they include forward guidance, large-scale asset purchases (quantitative easing or QE) and funding for credit (providing funding directly to key sectors of the economy). Bank of Canada (2015) discusses several alternatives for providing stimulus when interest rates are low. It discusses forward guidance, negative interest rates, and supplying credit to specific sectors where credit markets are impaired, in addition to the use of large-scale asset purchases $(\mathrm{QE})$. The purpose of this E-Brief is to argue why QE should be favoured as an alternative.

2 There is a tradition going back (at least) to Laidler and Robson (1991) of encouraging the Bank of Canada to pay more attention to monetary aggregates for the analysis and conduct of its monetary policy, but this has very little currency at the Bank of Canada or at other major central banks. This E-Brief is intended as a contribution to this tradition. The following is a non-exhaustive list of C.D. Howe studies (or studies by scholars associated with the Institute) on the importance of money for monetary policy: Laidler and Robson (1991, 1995), Laidler (1999a, 1999b, 2004, 2007, 2012a, 2012b), Siklos (2010), Bergevin and Laidler (2011), and Dubrovinsky (2014). 
The Bank's description of how its monetary policy works (on its website) assigns no role at all to monetary aggregates. The latter are given brief mention in a technical report by Longworth (2003). He starts off by outlining the standard four-equation approach to monetary policy, and notes, "A fifth equation, a money-demand function, could be added to the model, but its only purpose would be to determine the stock of money, because money itself plays no role in the above equations."

In a brief section on money and its effects, Longworth states that there are three possible channels: a real balance effect if part of money is net wealth, a second real balance channel if real balances directly affect utility, and "disequilibrium effects, which arise if there is a buffer-stock role for money." On the latter, he writes (page 5):

The third channel, the buffer-stock role, has received much more attention in Canada, particularly because of the research done by Laidler and Robson (1995); see also Laidler (1999a, b). These authors concentrate on the dynamic process that occurs when interest rates are lowered, credit is created as banks grant loans, and the proceeds from the loans are placed in the borrowers' transaction accounts. This could create a gap between the public's actual and desired holdings of narrow money, which in turn could cause an increase in spending. The proponents of this view admit that whether these events will indeed occur in this fashion is an empirical matter, but they point to the leading information in M1 for output and perhaps inflation as an indication that the buffer-stock role may be empirically important in Canada.

No mention is made in the study of broader monetary aggregates.

\section{Providing Stimulus through QE}

The first line of approach when using QE to provide stimulus is the use of classic open market operations; the purchase of government securities from the banking sector. Banks acquire deposits with the Bank of Canada and under normal circumstances will have an incentive to expand their lending activity, leading to an increase in deposits and therefore to an increase in broader measures of the money supply.

This would require a slight tweaking of the Bank's current operating procedures. Since the abolition of required reserves, banks no longer have the legal obligation to maintain a minimum level of deposits (reserves) at the Bank of Canada. Canada's monetary base (narrow money supply) consists almost exclusively of currency in circulation. Banks do maintain balances with the Bank of Canada for settlement purposes. The Bank of Canada aims for these balances to be close to zero at the end of each trading day.

Until 2009, the Bank of Canada had a target of $\$ 25$ million for daily settlement balances. This was increased to $\$ 3$ billion in April 2009 as a result of the financial crisis. ${ }^{3}$ Subsequent to $9 / 11$ and also subsequent to the Lehman Brothers bankruptcy in 2008, the Bank did provide liquidity to the financial system by purchasing securities, but these were purchased under repo agreements rather than being purchased outright. ${ }^{4}$

3 See Zorn, Wilkins and Engert $(2009,10)$.

4 Under Repo agreements the Bank buys securities from dealers who have agreed to repurchase them. On the liabilities side of its balance sheet, it was federal government deposits rather than deposits of banks that increased substantially after the Lehman Brothers bankruptcy. See Gordon (2009). 
In situations where the Bank's overnight target rate and other short-term interest rates are very low, banks could have little incentive to expand their loans. Short-term assets become almost perfect substitutes for currency. This situation has been termed a "liquidity trap" by a number of economists, alluding to Keynes' use of the term in a different context. Congdon $(2010,2011,2011$ b, 2012) would refer to a situation of low short-term interest rates as a "narrow" liquidity trap as opposed to Keynesian "broad" liquidity traps in which individuals cannot be persuaded to buy longer-term securities because they fear a capital loss that would ensue from an expected increase in longer-term rates of return.

Nevertheless, if banks do not have an incentive to lend and expand deposits, it would be difficult for the Bank of Canada to expand broader measures of the money supply (those that include various types of deposits by the private sector with chartered banks) by the use of classic open market operations. Instead, the Bank of Canada can directly expand broad money by purchasing assets from the private sector. Private-sector holdings of securities decrease while deposits with the banking system (counted as part of broad money) increase.

By buying up assets that are relatively illiquid, the central bank can influence the liquidity of individuals' (households and firms) portfolios. As long as they have a relatively stable preference for the ratio of liquid to total assets in their portfolios, individuals will run down their liquid assets by bidding up the prices of less liquid assets or by directly purchasing goods and services. ${ }^{5}$

While individuals can bring their own portfolios into balance, in aggregate the only way that this can happen is for nominal spending or the price level to increase, bringing the demand for broad money in line with the increased supply. This process is just the "musical chairs" or "hot potato" model of the effects of an increase in the money supply familiar from the monetarist literature on the effects of monetary policy, combined with the buffer-stock approach alluded to above in the quote from Longworth (2003). The buffer-stock approach holds that individuals will temporarily absorb increases in their holdings of money for precautionary purposes and will bring their long-run demand for money in line with their holdings of money by altering their spending patterns. ${ }^{6}$ At the end of the day, if households and firms maintain a stable ratio of liquid to total assets this "hot potato" model can increase spending without forcing a lowering of interest rates.

What evidence is there that such a mechanism is important? First, it is important to note that $\mathrm{QE}$ as practised by central banks like the Fed, the Bank of England, the Bank of Japan, and the European Central Bank in the aftermath of the financial crisis of 2007-2008 was not in general very effective due to the prevailing "credit channel" view of how QE operates. ${ }^{7}$ This view holds that QE operates via two main mechanisms. First, QE can provide liquidity to markets where liquidity is in short supply due to financial crisis: examples include the drying up of the interbank loan market in the US and the asset-backed commercial paper market in Canada during the financial crisis. Second, by purchasing longer-term securities the central bank can drive up their price and lower

5 The stability of the ratio of liquid to total assets is an empirical matter. It holds more closely for broader measures of money and for divisia, or weighted, monetary aggregates as opposed to simple-sum aggregates. See Belongia and Ireland $(2012,2015)$.

6 See Laidler (1984) for a detailed description of this theory.

7 The Bank of Canada's own description of the effects of QE is similar to that of much of the modern literature. See for example Santor and Suchanek (2013) and Reza, Santor and Suchanek (2015). For details on how QE was implemented in the Eurozone, Japan, the United Kingdom and the US see Fawley and Neely (2013). 
their yield. This drives down the yield curve at longer horizons and can help stimulate spending. Empirical work on the effects of QE on the yield curve find small quantitative effects often measured in tens of basis points rather than in percentage points. ${ }^{8}$

For QE to be effective, it must be the case as noted by Buiter (2014) that money provides benefits beyond its pecuniary rate of return. This is necessary in order that people continue to hold money that is dominated in rate of return by non-monetary assets with a positive nominal interest rate. Buiter notes (page 1) that in a cashless economy "like the Woodford-Galí (Woodford 2003, Galí 2008) worlds in which something called "money" serves as a numéraire but either has no existence as a store of value (currency, an account with the Central Bank or e-money) or yields no non-pecuniary benefits," QE cannot be effective.'

There is abundant evidence in the literature that in order for an open market operation to have a strong effect on inflationary expectations and aggregate demand, it must be very persistent if not permanent. QE as practised by central banks since the financial crisis has for the most part been explicitly designed to be temporary. In some cases central bank purchases of securities were sterilized so that there was no net effect on the central bank's balance sheet. Beckworth (2014) argues that QE in the US has had a limited impact on broad measures of money and on nominal income because it is expected to be temporary. ${ }^{10}$ Woodford (in Reichlin, Turner and Woodford 2013) notes:

Under quantitative easing, people might not expect the increase in the monetary base to be permanent after all, it was not in the case of Japan's quantitative easing policy in the period 2001-2006, and US and UK policymakers insist that the expansions of those central banks' balance sheets won't be permanent, either - and in that case, there is no reason for demand to increase.

In order for $\mathrm{QE}$ to be effective, it is essential that a central bank credibly establish some sort of firm end point for the level of a nominal aggregate, which could be the level of nominal income, or the future level or path of the price level. $^{11}$

The monetarist argument for $\mathrm{QE}$ is that by influencing the size of a suitable monetary aggregate, the central bank can influence the volume of nominal spending in the economy. This is just a consequence of the proposition of long-run monetary neutrality. ${ }^{12}$ Although monetarism has fallen into some disfavour among

8 See for example Swanson and Williams (2014).

9 Such cashless economies are (not surprisingly) also the mainstay of today's central bank forecasting models.

10 Ambler (2016) shows in a standard New Keynesian model with a genuine role for money that temporary QE has limited effects on inflation and real activity. See also Rowe (2016) on the importance of permanence.

11 This buttresses the argument for level targeting of some kind. This takes us too far from the main point of this E-Brief, and will be developed elsewhere.

12 The velocity of circulation may change in the long run, but the central bank can in principle react to such changes in order to attempt to keep nominal spending on a stable growth path. Secular and short-run changes in velocity contributed to monetary aggregates falling from favour as targets for central banks. This would argue, as noted in the text, in favour of level targets such as a path for the price level or for nominal spending to make permanent increases in broad money stocks credible. 
macroeconomists, the long-run monetary neutrality proposition still enjoys a broad consensus. ${ }^{13} \mathrm{QE}$ can also affect inflation expectations at longer horizons, which has the effect of lowering ex ante real interest rates and stimulating spending.

Much of the evidence in support of the monetarist view comes from the Great Recession. The monetarist interpretation holds that monetary policy in the US was too tight during the early part of 2008, turning a potentially mild recession into the worst recession (in the US) since the Great Depression. Broad money aggregates were allowed to drop precipitously in the US, Canada, the United Kingdom and the Eurozone at the onset of the Great Recession. Until very recently, broad money growth in the United Kingdom and the Eurozone has been weak, contributing to double-dip recessions in these economies. (The Appendix contains a detailed summary of the monetarist interpretation of the Great Recession and relevant references.)

There has been much confusion in the academic and popular literature concerning how QE and so-called "helicopter drops" of money are related. The latter are usually interpreted to mean a coordinated effort by a central bank and a treasury to permanently inject money into the economy. One possible mechanism (the one most commonly alluded to) is for the treasury to borrow money directly from the central bank and to send a rebate to households, who deposit their rebate checks in their bank accounts, thereby increasing broad money. Explicit coordination between the treasury and the central bank is required, and the balance sheet of the treasury is directly affected by such a series of transactions.

If the central bank purchases treasury securities from the private sector, the balance sheet of the treasury seems to be unaffected. However, its intertemporal budget constraint (ie., decisions for the present and future) is affected. The treasury has to pay interest on the securities to the central bank rather than to the private sector, and the central bank remits these payments back to the treasury as part of its operating profits. Insofar as the central bank's injection of money is permanent, the treasury will be able to increase its spending or to reduce taxation at some point in time. The central bank's action does therefore have fiscal consequences, but explicit coordination between the central bank and the treasury is not required for the central bank to expand the broad money supply. ${ }^{14}$

\section{Conclusions}

The Bank of Canada should aim to provide monetary stimulus through open market operations or through direct purchase of securities from the private sector. This may require some rethinking of the way monetary policy is currently conducted. At present, base money consists almost entirely of notes and coins in circulation. The Bank conducts its operations so that settlement balances held by members of the Canadian Payments Associations net out approximately to zero by the end of each trading day. During 2009, the Bank did allow for positive settlement balances through its Purchase and Resale Agreement ("PRA") program (essentially acquiring assets via longerterm repurchase agreements), but as we have seen the objective of the program was to provide liquidity in the short term, not to expand the monetary base in the longer term.

13 See Benati (2012) for empirical evidence and Nelson (2008) on the long-run link between money growth and inflation.

14 Cohen-Setton (2015) develops in greater detail the argument for the equivalence of $\mathrm{QE}$ and helicopter money. For a critical view of helicopter money, see Borio and Disyatat (2016). 
The Bank's operating procedures (particularly the goal of achieving close to zero net settlement balances each day) seem almost designed to eliminate the possibility of permanent increases in the monetary base via open market operations. The Bank should think carefully about how to adapt these operating procedures in an environment with a zero or negative overnight rate before it finds itself stuck there. The Bank should also devote some resources, after what has been a long hiatus, to looking at the informational content and economic significance of monetary aggregates. As discussed by Congdon (2011), Laidler (2012), Thornton (2014), and many others, increases in the money supply can have powerful real effects even at very low interest rates. 


\section{Appendix:}

\section{For “Putting Money to Work: Active Monetary Policy in a Low Interest Rate Environment" by Steve Ambler.}

\section{A Monetary Interpretation of the Great Recession}

Whether or not the Fed's accommodative policies earlier in the decade contributed to a housing bubble that led to the financial crash, a strong case can be made that the stance of monetary policy during the first three quarters of 2008 was overly restrictive. This is the basis of the monetary view of the Great Recession. Its most persuasive advocates include Beckworth (2010, 2012), Christensen (2011), Cole and Nunes (2013), Congdon (2009, 2011, 2012, 2014), Hetzel (2009, 2012), Hummel (2011), Johnson (2011), and Sumner (2013, 2015) among others.

The monetary narrative can be summarized as follows. The rise in oil prices in 2007 put upward pressure on inflation: by June 2008, oil prices had more than doubled over the previous year. Because of the inflation scare, the Fed kept its target for the Federal Funds Rate relatively high throughout the first part of 2008, even though the US economy had already entered a recession (the NBER Business Cycle Dating Committee dates the beginning of the Great Recession in the US as December 2007).

Economic activity continued to fall throughout 2008 as did inflation, so real interest rates actually increased over the year. The decline in real activity accelerated throughout 2008: payroll employment declined by 47,000 per month from January to March, by 207,000 per month from April to July, by 267,000 in August and by 434,000 in September even before the failure of Lehman Brothers on September 15 (Hetzel 2012). The Fed funds target was lowered to 2.00 percent in April 2008 but was kept constant until after the Lehman bankruptcy. It was lowered to 1.50 percent subsequent to a conference call on October 8 and then lowered to 0.25 percent at the meeting of December 16.

The Fed's restrictive monetary policy was compounded by an increase in the demand for liquidity in general, and narrow money (currency in circulation) in particular, due to a flight to safety starting with the asset-backed commercial paper crisis in August 2007 and then accelerating with the Lehman Brothers failure in September $2008 .{ }^{15}$

Shocks to the velocity of narrow money, as well as a drop in the money multiplier, were a leading indicator of the precipitous drop in nominal income that occurred starting in the fourth quarter of 2008. The recession then spread to other industrialized economies. In the case of Canada, a major impetus was the negative shock to the demand for Canadian exports.

Figure 1 below shows that for Canada and other major industrialized economies (the US, the Eurozone, and the United Kingdom), broad money growth (which includes, for example, demand deposits at banks), after accelerating before 2008, started falling sharply in 2008 or early 2009. Japan is the exception here: the rate of

15 Beckworth (2010) develops this argument. 


\section{Figure 1: Broad Money Growth in Major Economies}

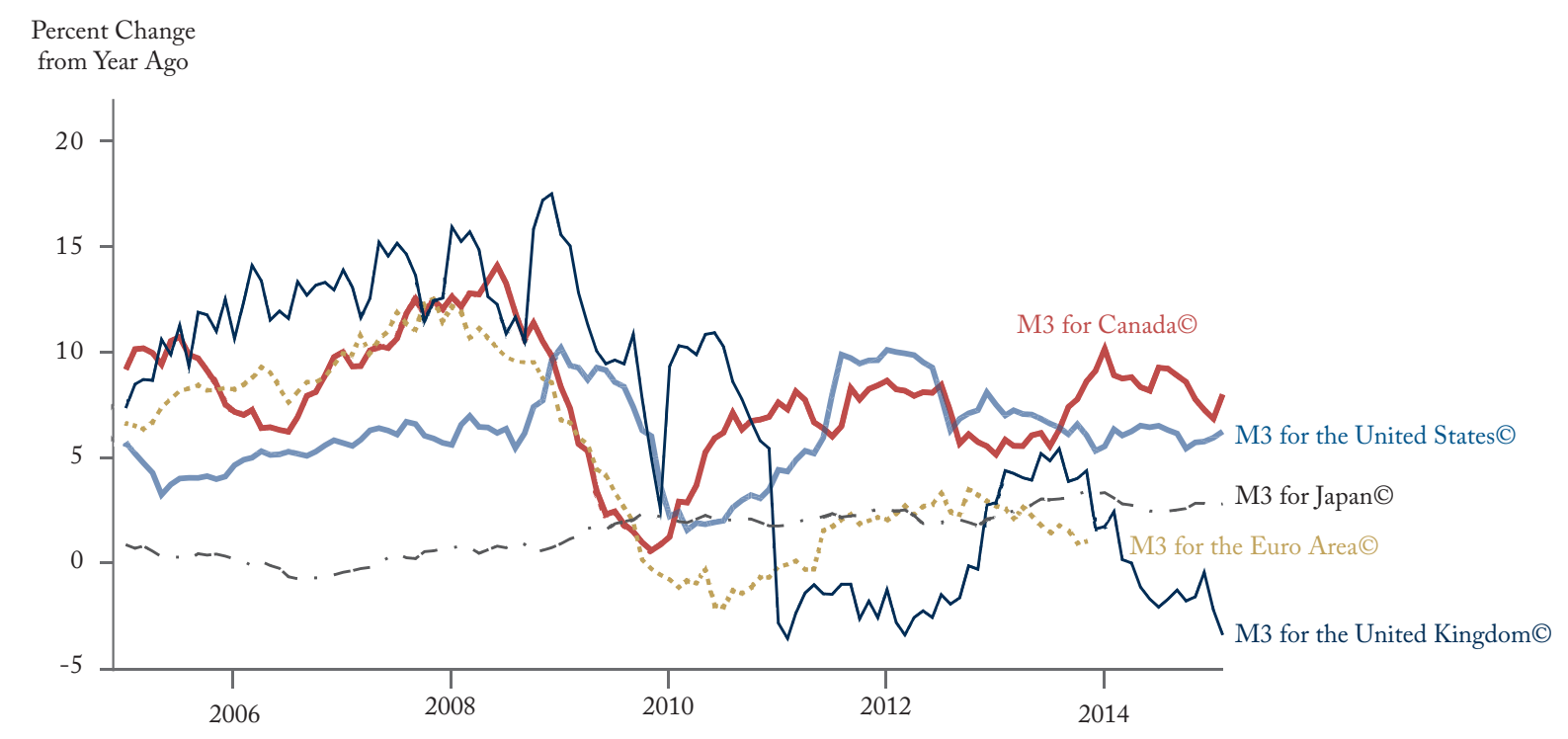

Source: 2015 research.stlouisfed.org.

growth of broad money was already very low before the beginning of the financial crisis. ${ }^{16}$ Empirical evidence ${ }^{17}$ shows that broader measures of money are more tightly linked to nominal spending than narrow measures. ${ }^{18}$

Correlation is not causation, but the evidence is interpreted by the advocates of the monetary approach to suggest that major central banks allowed money growth to fall and that this may have at least contributed to turning a mild recession into the most important worldwide recession since the Great Depression.

The response of major central banks to the onset of the Great Recession was guided by the importance they gave to the "credit channel" view of monetary policy transmission. ${ }^{19}$ According to this view, the volume of bank loans determines aggregate spending and real activity. The key to getting the economy back on track was to extend credit to the banking system (including shadow banks) in order to unblock seized-up credit markets, reduce credit spreads between risky and safe assets, and get the banks to lend again.

16 The US stopped publishing data on $M 3$ in 2006. This reinforces the idea that monetary aggregates are no longer seen as a useful input into the monetary policy process. The $M 3$ series in the figure is calculated by the OECD based on data provided by the Fed.

17 See Belongia and Ireland $(2012,2015)$ and Congdon $(2009,2011,2012,2014)$.

18 See for example Congdon (2010, 2011, 2014).

19 See Congdon (2014) for a critique, Bernanke and Gertler (1995) for a broad summary and Bernanke and Blinder (1988) for an early statement. 
The Fed, the Bank of Canada, and other major central banks provided extraordinary liquidity facilities to major financial institutions that were experiencing difficulty obtaining short-term financing. The Bank of Canada's balance sheet expanded rapidly in late 2008 in conjunction with this provision of liquidity before shrinking back almost to its pre-crisis level by the middle of 2010. The Fed went further by deciding to accept low-quality collateral against loans to financial institutions, to charge subsidy (instead of penalty) rates for those loans, and to rescue firms that were deemed too big to fail (such as Citigroup and AIG) without announcing a well-defined set of policies for how it would act as a lender of last resort. ${ }^{20}$

The lack of a set of ex ante policies led to moral hazard problems. One of the reasons for the enormous impact of the Lehman Brothers collapse on financial markets was the widespread expectation beforehand that it would be bailed out as Bear Sterns had been earlier the same year. ${ }^{21}$

The expansion of the Fed's balance sheet starting in 2009 was accompanied by a fall both in the money multiplier and the velocity of circulation of most monetary aggregates. The fall in the money multiplier can partly be explained by the policy, introduced in October 2008, of paying interest to banks on their excess holdings of reserves. ${ }^{22}$ This created a disincentive for banks to lend. In a climate with persistent low rates of return and high uncertainty, banks could earn low but safe rates of return by leaving reserves parked with the Fed. The Fed itself grew into a gigantic financial intermediary, essentially borrowing from the financial system in order to hold large quantities of non-traditional assets (such as mortgage-backed securities) on its books. ${ }^{23}$

The expansion of the Fed's balance sheet took place as part of three separate episodes of $\mathrm{QE}$ in which the balance sheet of the Fed expanded considerably, as did narrow and broad measures of money. This probably did help prevent a slump of the magnitude of the Great Depression, but nominal income in the US remained on a permanently lower growth path than it was on before the onset of the Great Recession. ${ }^{24}$

The credit channel also gave rise to an impetus to recapitalize the banking system. The push to recapitalize banks itself had the effect of putting a brake on the rate of growth of broad measures of the money supply, as argued by Hanke (2013).

There are two reasons for this. First, banks can alter the composition of the liabilities side of their balance sheets either by raising new capital or by shrinking the size of their deposits. If they shrink their deposits, this obviously reduces broad measures of the money supply. If they raise new equity, investors typically exchange funds from bank deposits for bank shares, which also extinguishes money. Second, banks can also change the composition of the asset side of their balance sheets by holding more cash and government securities (which have lower capital requirements) and reducing the size of their loan books, which will reduce the

20 See Humphrey (2010) for an analysis.

21 See Roberts (2010) for details of the effects that Bear Sterns had on the market's assessment of the likelihood of a bailout of Lehman Brothers.

22 Hummel (2011) and Johnson (2011) contain penetrating analyses of this phenomenon.

23 Hummel (2011) and Cochrane (2012) both judge that the Fed morphed during this period from a traditional central bank to a central planner that allocates funds preferentially by sector of the economy and by firm.

24 In line with the credit channel view of the Great Recession, most empirical work on the effectiveness of QE in the US and elsewhere has concentrated on its effects on the term structure of interest rates, and in particular on rates of return at longer horizons. See Santor and Suchanek (2013) for a survey. 
amount of multiple deposit creation familiar from money and banking textbooks. As Hanke (2013) writes, "So, paradoxically, the drive to deleverage banks and to shrink their balance sheets, in the name of making banks safer, destroys money balances. This, in turn, dents company liquidity and asset prices. It also reduces spending relative to where it would have been without higher capital-asset ratios."

The expansion of the Bank of Canada's balance sheet was almost entirely related to providing short-term liquidity to Canadian financial institutions, in line with the credit view of the transmission of financial shocks. ${ }^{25}$ On the asset side, the Bank acquired a mixture of private-sector assets including bankers' acceptances, commercial paper, asset-backed commercial paper and corporate bonds. The program was also explicitly designed so that these assets would be automatically liquidated upon the maturity of the loans as the need to provide liquidity to the banking system diminished.

The Bank established reasonably clear guidelines for its lending practices and recognized the importance of moral hazard. ${ }^{26}$ Since the 2008 recession in Canada was milder than in most industrialized economies (and milder than other post-war Canadian recessions), the focus on liquidity provision was appropriate.

25 Chart 1 in Lavoie, Sebastian and Traclet (2011) compares the provision of liquidity by the Bank of Canada and the Fed. By their measure the Fed's liquidity provision had shrunk almost to zero by the end of 2009. This means that most of the vast expansion of the Fed's balance sheet after 2009 did not fall into this category.

26 See Longworth (2010). 


\section{References}

Ambler, Steve. 2016. “A Tale of Two Velocities.” Draft, École des sciences de la gestion (ESG).Université du Québec à Montréal (UQAM). http://www.steveambler.uqam.ca/papers/velocitypuzzle.2015.pdf.

Bank of Canada. 2012. "How Monetary Policy Works: The Transmission of Monetary Policy.” Backgrounder. http://www.bankofcanada.ca/wp-content/uploads/2010/11/how_monetary_policy_ works.pdf.

.2015. "Framework for Conducting Monetary Policy at Low Interest Rates." http://www. bankofcanada.ca/wp-content/uploads/2015/12/framework-conducting-monetary-policy.pdf.

Beckworth, David. 2010. “The Great Liquidity Demand Shock.” Macro and other Market Musings. December 30. http://macromarketmusings.blogspot.ca/2010/12/great-liquidity-demand-shock.html. (ed.). 2012. Boom and Bust Banking. Oakland, CA: Independent Institute. http:// macromarketmusings.blogspot.ca/2013/12/the-wrong-debate-helicopter-drops-vs.html.

2014. “The Fed's Dirty Little Secret.” Macro and other Market Musings. December 22. http://macromarketmusings.blogspot.ca/2014/12/the-federal-reserves-dirty-little-secret.html.

Belongia, Michael, and Peter Ireland. 2012. "Quantitative Easing: Interest Rates and Money in the Measurement of Monetary Policy.” Working Paper 801, Department of Economics, Boston College. http://www.bc.edu/content/dam/files/schools/cas_sites/economics/pdf/workingpapers/wp801.pdf.

2015. "Interest Rates and Money in the Measurement of Monetary Policy." Journal of Business and Economic Statistics 33: 255-269.

Benati, Luca. 2009. “Long Run Evidence on Money Growth and Inflation.”Working Paper 1027, European Central Bank. http://www.ecb.europa.eu/pub/pdf/scpwps/ecbwp1027.pdf.

Bergevin, Philippe, and David Laidler. 2011. Putting Money Back into Monetary Policy: A Monetary Anchor for Price and Financial Stability. Commentary 312. Toronto: C.D. Howe Institute. October.

Bernanke, Ben, and Alan Blinder. 1988. "Credit, Money and Aggregate Demand." American Economic Revierw 78: 435-439.

Bernanke, Ben, and Mark Gertler. 2005. "Inside the Black Box: The Credit Channel of Monetary Policy Transmission." Journal of Economic Perspectives 9: 27-48.

Borio, Claudio, Piti Disyatat, and Anna Zabai. 2016. "Helicopter Money: The Illusion of a Free Lunch.” Vox. May 24. http://voxeu.org/article/helicopter-money-illusion-free-lunch.

Buiter, Willem. 2014. "The Simple Analytics of Helicopter Money: Why It Works - Always." Economics: The Open-Access, Open-Assessment E-Journal 8: 2014-2028. http://dx.doi.org/10.5018/economicsejournal.ja.2014-28.

Christensen, Lars. 2011. "Market Monetarism: The Second Monetarist Counter-Revolution.” Draft. https://thefaintofheart.files.wordpress.com/2011/09/market-monetarism-13092011.pdf. 
Cochrane, John. 2012. The Federal Reserve: From Central Bank to Central Planner. Commentary. Cato Institute. http://www.cato.org/publications/commentary/federal-reserve-central-bank-central-planner.

Cohen-Setton, Jérémie. 2015. “Permanent QE and Helicopter Money.” Bruegel Blog. January 5. http:// www.bruegel.org/nc/blog/detail/article/1527-permanent-qe-and-helicopter-money/.

Cole, Benjamin, and Marcus Nunes. 2013. Market Monetarism: Roadmap to Economic Prosperity. Marcus Nunes.

Congdon, Tim. 2009. “The Unnecessary Recession.” Standpoint. http://standpointmag.co.uk/theunnecessary-recession-features-june-09-tim-congdon-gordon-brown-alistair-darling.

.2010. “Monetary Policy at the Zero Lower Bound.” World Economics 11: 11-46.

2011. Money in a Free Society. London: Encounter Books.

. 2011b. “Dangerous Waffle about “the” Liquidity Trap.” Cato Unbound. December. http:// www.cato-unbound.org/issues/december-2011/will-real-john-maynard-keynes-please-stand.

.2012. "Liquidity Trap Claptrap." Economic Affairs 32: 101. http://onlinelibrary.wiley.com/ doi/10.1111/j.1468-0270.2012.002141.x/abstract.

.2014. "What Were the Causes of the Great Recession? The Mainstream Approach vs the Monetary Interpretation.” World Economics 15: 1-32.

Dubrovinsky, Mati. 2014. "Money Still Matters: How the Bank of Canada Might Better Monitor Inflation.” E-Brief 180. Toronto: C.D. Howe Institute. August.

Fawley, Brett, and Christopher Neely. 2013. "Four Stories of Quantitative Easing." Federal Reserve Bank of St. Louis Review 95: 51-88.

Galí, Jordi. 2008. Monetary Policy, Inflation and the Business Cycle. Princeton: Princeton University Press.

Gordon, Stephen. 2009. “The Evolution of the Bank of Canada's Balance Sheet.” Worthwhile Canadian Initiative. April 8. http://worthwhile.typepad.com/worthwhile_canadian_initi/2009/04/theevolution-of-the-bank-of-canadas-balance-sheet.html.

Hanke, Steve. 2013. “Basel's Capital Curse.” Globe Asia. January, 18-22. http://www.centerforfinancialstability. org/oped/BaselsCapCurseJan2013.pdf.

Hetzel, Robert. 2009. "World Recession: What Went Wrong?” Economic Affairs 29 n(3): 17-21.

.2012. The Great Recession: Market Failure or Policy Failure? Cambridge: Cambridge University Press.

Hummel, Jeffrey. 2011. “Ben Bernanke versus Milton Friedman : The Federal Reserve's Emergence as the U.S. Economy's Central Planner.” The Independent Review 15: 485-518.

Humphrey, Thomas. 2010. "Lender of Last Resort: What It Is, Whence It Came, and Why the Fed Isn't It.” Cato Journal 30: 333-364.

Ireland, Peter. 2005. “The Monetary Transmission Mechanism.” Working Paper 06-01. Federal Reserve Bank of Boston. http://www.bostonfed.org/economic/wp/wp2006/wp0601.pdf. 
Johnson, H. Clark. 2011. "Monetary Policy and the Great Recession.” The Milken Institute Review Fourth Quarter: 17-26.

Laidler, David. 1984. “The 'Buffer Stock’ Notion in Monetary Economics.” Economic Journal 94: 17-34

. 1999a. "Passive Money, Active Money and Monetary Policy." Bank of Canada Review Summer: 15-26.

.1999b. "The Quantity of Money and Monetary Policy.”Working Paper 99-5, Bank of Canada. http://www.bankofcanada.ca/1999/04/working-paper-1999-5/.

.2004, "Monetary Policy after Bubbles Burst: The Zero Lower Bound, the Liquidity Trap and the Credit Deadlock." Canadian Public Policy 30: 333-340.

2007. Better Late Than Never: Towards a Systematic Review of Canada's Monetary Policy

Regime. Commentary 252. Toronto: C.D. Howe Institute.

Institute.

2012a. "Money Still Talks - Is Anyone Listening?” E-Brief 133. Toronto: C.D. Howe

.2012b. “Two Crises, Two Ideas, and One Question.”Working Paper 2012-04.

Economic Policy Research Institute, University of Western Ontario. http://economics.uwo.ca/epri/ workingpapers_docs/wp2012/Laidler_04.pdf.

Laidler, David, and William Robson. 1991. Money Talks - So Let's Listen. Commentary 26. Toronto: C.D. Howe Institute.

. 1995. "Endogenous Buffer-Stock Money." In Credit, Interest Rate Spreads and the Monetary Policy Transmission Mechanism. Ottawa: Bank of Canada, 231-258.

Lavoie, Stéphane, Alex Sebastian, and Virginie Traclet. 2011. "Lessons from the Use of Extraordinary Central Bank Liquidity Facilities.” Bank of Canada Review Spring, 27-36.

Longworth, David. 2003. "Money in the Bank.” Technical Report 93, Bank of Canada. http://www. bankofcanada.ca/2003/02/technical-report-no93/.

. 2010. "Bank of Canada Liquidity Facilities: Past, Present, and Future.” Remarks to the C.D. Howe Institute, Toronto, February 17. http://www.bankofcanada.ca/2010/02/liquidity-facilitiespast-present-future/.

Nelson, Edward. 2008. "Why Money Growth Determines Inflation in the Long Run: Answering the Woodford Critique.” Journal of Money, Credit and Banking 40: 1791-1814.

Poloz, Stephen. 2015. "Prudent Preparation: The Evolution of Unconventional Monetary Policies." Remarks to the Empire Club of Canada. Toronto. December 8. http://www.bankofcanada. ca/2015/12/prudent-preparation-evolution-unconventional-monetary-policies/.

Reichlin, Lucrezia, Adair Turner, and Michael Woodford. 2013. "Helicopter Money as a Policy Option." Vox EU. May 20. http://www.voxeu.org/article/helicopter-money-policy-option.

Reza, Abeer, Eric Santor, and Lena Suchanek. 2015. "Quantitative Easing as a Policy Tool under the Effective Lower Bound.” Discussion Paper 2015-14, Bank of Canada. http://www.bankofcanada. ca/2015/11/staff-discussion-paper-2015-14/. 
Roberts, Russell. 2010. "Gambling with other People’s Money: How Perverted Incentives Caused the Financial Crisis.” Mercatus Center, George Mason University. http://mercatus.org/publication/ gambling-other-peoples-money.

Rowe, Nicholas. 2016. “Helicopter Money is Permanent.” Worthwhile Canadian Initiative. April 4. http:// worthwhile.typepad.com/worthwhile_canadian_initi/2016/04/helicopter-money-is-permanent.html.

Santor, Eric, and Lena Suchanek. 2013. "Unconventional Monetary Policies: Evolving Practices, Their Effects and Potential Costs." Bank of Canada Review Spring, 1-15.

Siklos, Pierre. 2010. “Taking Monetary Aggregates Seriously.” E-Brief 94. Toronto: C.D. Howe Institute.

Sumner, Scott. 2013. “A New View of the Great Recession.” Policy (29): 19-25.

2015. “The Real Problem was Nominal: The Crash of 2008.” Adam Smith Institute. http:// www.adamsmith.org/wp-content/uploads/2015/02/therealproblemwasnominal2.pdf.

Swanson, Eric, and John Williams. 2014. "Measuring the Effect of the Zero Lower Bound on Mediumand Longer-Term Interest Rates." American Economic Review 104: 3154-3185.

Thornton, Daniel. 2014. "Monetary Policy: Why Money Matters (and Interest Rates Don't)." Journal of Macroeconomics 40: 202-213.

Woodford, Michael. 2003. Interest and Prices: Foundations of a Theory of Monetary Policy. Princeton: Princeton University Press.

Zorn, Lorie, Carolyn Wilkins, and Walter Engert. 2009. "Bank of Canada Liquidity Actions in Response to Financial Market Turmoil.” Bank of Canada Review Autumn, 3-22.

This E-Brief is a publication of the C.D. Howe Institute.

Steve Ambler is the David Dodge Chair in Monetary Policy at the C.D. Howe Institute, professor in the Economics Department at the Université du Québec à Montréal, senior fellow of the Rimini Centre for Economic Analysis, and a member of the Inter-University Centre on Risk, Economic Policies and Employment (CIRPEE).

This E-Brief is available at www.cdhowe.org.

Permission is granted to reprint this text if the content is not altered and proper attribution is provided. 